\title{
JOE BIDEN'S STATEMENT ON 1915 EVENTS: PURPOSEFUL POLITICAL ACTIONS MAY CAUSE UNANTICIPATED CONSEQUENCES, AN ANALYSIS FROM THE SOCIOLOGICAL VIEWPOINT
}

\section{Teoman Ertuğrul TULUN}

\section{Analyst}

American sociologist Robert Merton, in his article titled The Unanticipated Consequences of Purposive Social Action, explained the historical background of the unanticipated consequences of purposeful actions and discussed the impact of these actions on society and its individuals.[1] He stated that unforeseen consequences, separate from desirable foreseeable consequences, are necessarily undesirable from the standpoint of the actor (the decision-maker). For though these results are unintended, they are not upon their occurrence always deemed axiologically negative. According to Merton, the intended and anticipated outcomes of purposive action are always, in the very nature of the case, relatively desirable to the those who take the action. In the case of states, those who take actions can be considered as political decision makers. Merton asserts that these actions may seem axiologically negative to an outside observer who was negatively affected by the decision. Merton points out that the effects of the unintended consequences of purposeful actions differ between the decision-maker of the action and the other side who will be adversely affected from this action. Taking Mertons approach as a basis, it should be considered that even if the main purpose of the decision-making is not to harm or victimize the other side, the consequences of purposeful actions can cause irritation in the other side adversely affected by the action. This may lead to the emergence of strong reactions at the societal level in the adversely affected side. In this framework, it would be worthwhile to briefly evaluate the recent statement by the US President Joe Biden on the 24 April Armenian Remembrance Day in terms of Robert Mertons notable concept of unintended consequences.[2]

Certain political commentators draw attention to several terms and expressions used in the mentioned statement such as Ottoman era, Ottoman authorities, Constantinople, and we do this not to cast blame. They assert that the statement, in its essence, tries to avoid targeting the Republic of Turkey and Turks and confines its accusations to the Ottoman authorities. Considering only the writing style of the statement, as in remaining at the superficial level, it is possible to get such an optimistic impression. However, from a careful reading, it is not difficult to understand that such terms and expressions are meant to camouflage an unacceptable terminology (genocide) that is used both at the beginning and the end of the statement. It is also possible to say that such an effort 
reflects a purposeful action to demonstrate to the adversely affected (Turkish) side that sufficient attention has been paid to them while preparing the statement.

Yet, the entirety of the text and the main purpose of the preparation of the statement reveal who and which nationalities or nations are targeted positively and negatively. In the text, one side (Armenian) is historically pampered and honored, while the other side (Turkish) is aggrieved for the main purpose of the preparation of the statement even if it is not intentional and sought to be avoided. This result, in my judgement, is compatible with the unintended consequences concept of Robert Merton and the process he described for reaching such a conclusion.

Individuals who consider themselves being treated unfairly usually develop their reactions at the societal level independent of the state level reactions against the actors they think have treated them unfairly. In this sense, societies, like states, have an instinct to protect themselves. This type of behavior is also valid for the Turks who will think that an injustice has been done to them within the framework of Bidens statement. It is highly likely that this statement will be viewed as an unjust accusation and attack against Turkish identity by a significant portion of the Turkish people. It would not be surprising that such an interpretation will lead to an increase in the need inevitably felt to protect Turkish identity, resulting in increased levels of nationalist and anti-imperialist sentiments in the short and medium term.

*Photo: https://egeada2.angelfire.com/

[1] Robert K. Merton, The Unanticipated Consequences of Purposive Social Action, American Sociological Review 1, no. 6 (December 1936): 894】 https://doi.org/10.2307/2084615.

[2] Statement by President Joe Biden on Armenian Remembrance Day (The White House, April 24, 2021), Statments and Relseases, https://www.whitehouse.gov/briefingroom/statements-releases/2021/04/24/statement-by-president-joe-biden-on-armenianremembrance-day/.

About the Author:

Teoman Ertuğrul Tulun is an analyst at Ankara-based think-tank Center for Eurasian Studies. He is a PhD Candidate at Bilkent University Department of Political Science and Public Administration. His area of research include European Union Studies, Social Movements, Xenophobia and Hate Speech Studies and State Building Studies.

To cite this article: TULUN, Teoman Ertuğrul. 2021. "JOE BIDEN'S STATEMENT ON 1915 EVENTS: 


\section{(2) AViM}

Süleyman Nazif Sok. No: 12/B Daire 3-4 06550 Çankaya-ANKARA / TÜRKIYE

Tel: +90 (312) 43850 23-24 • Fax: +90 (312) 4385026

@avimorgtr

7 https://www.facebook.com/avrasyaincelemelerimerkezi

E-Mail: info@avim.org.tr

http://avim.org.tr

(C) 2009-2021 Center for Eurasian Studies (AViM) All Rights Reserved 